\title{
THE COMPETITION DISCOURSE AND NORTH-SOUTH RELATIONS
}

\author{
Nobody comes to invest because you have a tax treaty. When you see \\ the rationale to attract investment, it sounds laudable. But when you \\ look at the evidence, it's not the case. \\ - Tax treaty negotiator, African country
}

One reason that lower-income countries do not raise more tax revenue from multinational investors is tax competition. States can choose to exercise their sovereign right to tax as much as they like in principle, but in practice they are engaged in a strategic interaction that keeps effective tax rates down, enforced by mobile corporate capital and high-income labor. ${ }^{1}$ As capital has become more mobile over time, states have come to take this much more into account, engaging in what some have described as a "race to the bottom." 2 Tax competition is a manifestation of what is often called the structural power of business: companies' ability to shape the options available to governments without explicitly lobbying for a given outcome, since governments anticipate their preferences and fear the negative consequences of contravening them. ${ }^{3}$

Competition for inward investment is the single most commonly cited reason for why lower-income countries have signed, or should sign, tax treaties. Yet, as we saw earlier, they are a poor choice of tool, given the uncertainty about their positive effects and the certainty about their costs. This is not a scenario limited to tax treaties but one that applies to other forms of tax competition: the effects of tax incentives and even headline corporate tax rates often seem to be overestimated by policymakers. The evidence that governments engage in strategic interactions over taxation is much stronger than the evidence that those strategic interactions influence investment flows. To understand tax competition, we therefore need to consider it through a cognitive lens, as a social rather than a brute fact. The idea of tax competition, potent in political debates as well as 
economic decision making, is sustained regardless of the shaky evidence that it brings welfare gains, especially to lower-income countries. ${ }^{4}$

This chapter combines the insights from work on boundedly rational learning-especially on BITs-with the classic conception of policy diffusion through competition, or "race to the bottom." 5 As the evidence presented in this chapter shows, lower-income countries have indeed signed tax treaties in order to compete for inward investment. The evidence to justify this competition is weak, and treaty negotiators themselves are often skeptical that tax treaties will attract investment. Others in lower-income countries do subscribe to the competition approach, but may be relying on ideas as well as, or instead of, purely rational analysis of the costs and benefits. Tax treaties are, however, a harder case than BITs for theories of bounded rationality, because the costs are more immediate and certain than any potential benefits, and hence information on the costs might be expected to be more "available" to policymakers. It is therefore important to consider how policymakers evaluate the costs and benefits, taking into account that the salience of information about costs may vary.

The chapter then turns the logic of competition on its head, demonstrating that the conclusion of tax treaties with lower-income countries has often been driven by higher-income countries in pursuit of outward investment opportunities. Tax treaties confer benefits in a lower-income country on only those multinationals based in the other signatory country, giving these companies an advantage over their competitors, who in turn ask their home governments to conclude tax treaties. Anecdotal evidence confirms that this mechanism has played an important role in the initiation of tax treaty negotiations between higher-income and lower-income countries. This apparently simple observation is largely absent from discussions in the literature on both BITs and bilateral tax treaties. Competition for outward investment cannot explain why lower-income countries, which incur most of the costs of tax treaties, would acquiesce to requests from higher-income countries. The final task of this chapter is therefore to consider the means through which higher-income countries have influenced lower-income countries' willingness to reciprocate.

\section{Tax Competition}

Higher taxation need not necessarily have a negative effect on investment and growth, but governments must take into account the behavioral effects resulting from the impact of taxation on taxpayers' economic incentives. They may reduce the incentive to work and invest, increase the incentive to avoid or evade taxes 
altogether, or encourage mobile economic actors to seek out less onerous tax regimes.

While some of these incentive effects occur within each state regardless of the conditions outside, the effect of levying taxation on mobile taxpayers is to create strategic interactions between states, tax competition. A large number of studies have attempted to model how corporate income taxation in the host state affects inflows of FDI. Meta-analyses of these studies find that a one-point increase in the corporate tax rate reduces FDI inflows by either 3 percent or 1.7 percent. ${ }^{6}$ For lower-income countries, however, there is some econometric evidence that longterm investment may not be responsive to taxation, and especially to tax incentives. ${ }^{7}$ In surveys, too, international investors in lower-income countries tend to cite other, more fundamental factors such as infrastructure and education above taxation. ${ }^{8}$ Where FDI in lower-income countries is sensitive to tax competition, it may crowd out domestic investment and may be of a transitory, footloose kind that does not bring with it long-term benefits such as skills and technology transfer, or forward and backward linkages. ${ }^{9}$

Despite these limitations, tax competition is not merely a descriptive theory: it is a powerful idea that influences policy. There is an influential view in public choice economics, originating with Charles Tiebout, that competition between states for mobile factors of production is desirable because it will lead to the optimal balance between the provision of public services benefiting those factors of production and the levels of taxation levied on them. ${ }^{10}$ Conversely, others argue that states should cooperate to limit tax competition, which if unmitigated leads to negative externalities such as mutual erosion of tax bases and increased regressivity. ${ }^{11}$ There is, consequently, a broad consensus in the literature confirming strategic tax competition between governments. ${ }^{12}$ Corporation tax rates, for example, have fallen consistently since the 1960s, while burgeoning tax incentive regimes can be seen in both lower-income and higher-income countries, in spite of consistent advice from international organizations that such competition is unlikely to bring investment gains. ${ }^{13}$ There are caveats to this account: tax rates are not the only elements of tax policy that determine how much companies pay, and evidence also suggests that political factors such as governing party ideology and prevailing societal norms can limit the potency of tax competition. ${ }^{14}$

Tax competition as we discuss it here refers to "real" competition, which Peter Dietsch calls "luring," as opposed to virtual competition, or "poaching," when governments use tax rules to attract paper profits and portfolio income, detached from any real activity. ${ }^{15}$ The two are connected, since a multinational company that can avoid tax by moving its paper profits may not be so sensitive to real tax competition, and hence virtual tax competition may reduce the so-called real tax competition pressure on governments. ${ }^{16}$ While "poaching" by tax havens has 
dominated international relations scholarship on the international tax regime, this account is much more focused on the North-South politics of "luring."

\section{Bounded Rationality and Tax Competition}

As I noted earlier, the puzzle of widespread tax treaty adoption by lower-income countries resembles that for BITs in many respects: an apparent undervaluing of costs and overestimation of benefits, combined with the inconsistent evaluation of information drawn from other countries' experiences. The literature on the diffusion of BITs, in which Lauge Poulsen's Bounded Rationality and Economic Diplomacy is an influential contribution deploys a bounded rationality framework drawing from behavioral economics. ${ }^{17}$ This, in turn, derives from Daniel Kahneman and Amos Tversky's prospect theory, which argues that people making decisions under uncertainty employ "heuristics" as shortcuts to evaluate information. ${ }^{18}$ Rather than acting as Bayesian logic machines that evaluate all available information, people process information through a cognitivepsychological framework, privileging certain pieces of information and downplaying others.

In a study of public policymaking in Latin America, Kurt Weyland introduced the insights from prospect theory into studies of world politics. He began from three common heuristics that people use when evaluating information. First, the availability heuristic causes people to overvalue information that is more strikingfor example, information that is simpler to understand or more dramatic. Weyland suggests that this explains why policymakers pay more attention to reforms adopted by countries close to home, rather than evaluating the full range of alternatives from around the globe. Alternatively, policymakers may look more favorably on the evidence about a policy that conforms to their ideological preferences, in comparison with a policy that contradicts them..$^{19}$ Second, through the representativeness heuristic, people tend to overestimate how generalizable the information gleaned from a small number of observations is. This would explain why certain policies seem to explode, spreading rapidly among countries. This "deviates from rational learning, which requires a careful cost-benefit analysis that considers a longer track record." ${ }^{20}$ Instead, the "informational cascade" reaches a tipping point at which point countries stop accumulating new information and decide to adopt the policy. ${ }^{21}$ Finally, the anchoring heuristic is the mechanism by which the stickiness of an initial piece of information biases further analyses. This can explain the adoption of nearidentical policies by countries with diverse needs and contexts: policymakers have simply not studied their own problems and all potential solutions in detail. 
Weyland describes an S-shaped curve when policies diffuse, and as Poulsen's account makes clear, this fits the BITs story very well: at first, countries were quick to copy each other without a detailed consideration of the costs and benefits of signing BITs, creating an exponential increase. This trend was reversed once policymakers realized the costs could indeed be significant. ${ }^{22}$ Poulsen uses the availability heuristic to explain this pattern: lower-income countries entered into treaties without fully anticipating their consequences, because these consequences were remote and had lower salience, in comparison with the signal sent by their neighbors forging ahead with BIT signatures; they were slow to realize the implications for themselves when other countries experienced investor-state claims, especially when these claims were outside their own region, because the examples were, again, less salient. ${ }^{23}$

A bounded rationality approach differs from more sociological explanations because it is based on a change in policymakers' beliefs about cause and effect; to use March and Olsen's terms, a logic of consequences rather than appropriateness. ${ }^{24}$ As Martha Finnemore and Kathryn Sikkink argue, norms can reach a "tipping point," beyond which they become "standards of appropriate behaviour," effectively the default behavior for states. ${ }^{25}$ As the following chapter discusses, such a dynamic is clearly present within the technocratic expert community, but in this chapter our focus is on the causal ideas of tax competition held by actors with less specialist knowledge. The literature is not always clear about this distinction. For instance, when Frank Dobbin and colleagues laid out a typology of policy diffusion mechanisms, their "constructivism" category (now more commonly referred to as emulation) referred to the three means by which a policy might spread through its social acceptance as a policymaking norm: its adoption by countries that are seen as exemplars by others, its promulgation as a policy norm by expert groups even in the absence of an exemplar, and the adoption of a policy by countries sharing economic, social, political, or cultural similarities. ${ }^{26}$ In practice, all three of these routes could constitute a heuristic, and thus be consistent with a bounded rationality framing. Similarly, while international organizations are sites for socialization, shared membership also provides a heuristic. ${ }^{27}$ In several studies of different economic policy diffusion, Xun Cao finds that shared participation in intergovernmental organizations leads to diffusion through the "natural affinity" between members of the same intergovernmental organization, as well as through policy learning. ${ }^{28}$

Chang Lee and David Strang demonstrate a combination of bounded rationality and more intersubjective mechanisms in the example of changes in the size of the public sector in OECD countries. ${ }^{29}$ Policymakers privileged information from certain examples more than others: countries with which they had a stronger trading relationship, and the United States, which served uniquely as a "Stackelberg 
leader." ${ }^{30}$ They also gave more weight to information that was consistent with their "interpretive frame," a belief that downsizing will encourage economic growth. ${ }^{31}$ Information consistent with this frame appeared more "available" than information that was not: changes to public sector size that were followed by changes in economic performance in the direction supported by the theory led to public sector downsizing in other countries, but changes with a null or opposite effect to that anticipated did not lead to increases in the size of the public sector. We might regard the logic of tax competition to be a similar interpretive frame.

We can apply these insights to relax the assumption of rationality inherent to most discussions of tax competition. Under economic competition, strategic interaction between countries causes them to adopt policies in order to make them relatively more attractive to foreign investment or to gain relatively more favorable access to export markets. This may lead to the diffusion of particular policies among countries competing with each other, or to the adoption of different policies in order to compete. Tax competition, in particular, is a convergence on lower effective tax rates in the hope of attracting investment. That hope need not, however, be rational, in at least three ways.

First, in the choice of policy: the government of one country may respond to the adoption of a particular investment-promotion policy in a competitor country by adopting it, perhaps ignoring doubts about its efficacy because of a fear of losing investment. This may be a rational choice to take a risk-averse approach in the absence of evidence, a mechanism that has been described as "rational emulation." ${ }^{32}$ Nathan Jensen argues that at the US state level, tax incentives are used by governments, even when their effectiveness is questionable, as a creditclaiming device. ${ }^{33}$ It may also, in the language of prospect theory, be based on cognitive heuristics. States compete with each other over corporation tax, but there is evidence to suggest that such competition is far from purely rational. Some attempts to study structural power in practice have found that the perception of business power matters more than the reality; indeed, different perceptions of the disinvestment threat among different actors in a country can lead to different preferences. $^{34}$

Second, the choice of competitor country may be imperfectly rational. Quantitative models define competitor countries objectively, based on economic statistics (similarity in trade patterns, bond ratings, and infrastructure characteristics, for example), and hence implicitly assume that policymakers apply a similar evidence-based approach to determining the countries with which they compete..$^{35}$ Yet the logic of competition may also apply in a boundedly rational way, in which information about the actions of certain countries is more "available" than information on the actions of others, regardless of the extent to which they actually compete with each other. 
Finally, policymakers may have an imperfect understanding of the relationship between a particular reform and flows of trade and investment. As the example of anti-money-laundering rules shows, countries may adopt reforms on paper in order to send a signal to other countries and to investors, without real commitment to enforcing them. ${ }^{36}$ In corporation tax, policymakers' focus on the headline rate of tax may differ from businesses' interest in the effective rate, which is determined by other factors such as the generosity of capital allowances and the opportunities for profit-shifting. ${ }^{37}$

The possibility of bounded rationality in the operation of competition mechanisms is specifically excluded by many quantitative methodological designs, which identify competitive pressure by analyzing objective economic variables, assuming that policymakers with a competitive mentality have done the same. For example, Beth Simmons and Zachary Elkins examine the determinants of capital account, current account, and exchange rate liberalization, finding that economic competition drives the diffusion of such policies. ${ }^{38}$ Elkins and colleagues also find that potential host governments seem more motivated to sign BITs when countries whose exports compete in similar third markets, and countries whose economic fundamentals make them comparably "attractive" to investors have done so. ${ }^{39}$ It is possible that what is captured by emulation variables such as linguistic similarity and geographic proximity is not pure emulation but rather competition employing cognitive heuristics to identify competitors. Thus, the conceptual boundaries popularly used in the policy diffusion literature may obscure more complex mechanisms, which can be more readily uncovered using qualitative research.

\section{Bounded Rationality in the Case of Tax Treaties}

The technically complex, obscure, and low-salience nature of tax treaties makes them an ideal candidate for bounded rationality: the simplicity of the idea that tax treaties will attract investment by eliminating double taxation contrasts with their complex nature and uncertain effects. Specialized knowledge is required to assess the likely effects of tax treaties, yet evidence suggests that those calling the shots often fail to consult with revenue authority officials possessing such knowledge. Historically, many of these officials themselves lacked sufficient specialist knowledge to advise. According to a former technical adviser to Rwanda, which has renegotiated its treaty with Mauritius, the original agreement was "a classic case of somebody negotiating something they don't understand." ${ }^{40}$ A technical adviser at an international organization observed that lower-income countries 
often have contradictory policies within their tax codes, some of which are designed to maximize revenue, and others to give it away with the idea of attracting investment. "It's at that political, strategic level that more could be done" to improve such coherence. ${ }^{41}$

Although in one case a negotiator described having been asked by her finance ministry for an impact assessment, in many cases there is no detailed consideration of the costs and benefits by the lower-income country concerned, and no policy on which to base decisions - a point emphasized by Catherine Ngina $\mathrm{Mu}-$ tava in her study of African countries' approaches to negotiation. ${ }^{42}$ One negotiator told me that "we are thinking that we should have a policy." ${ }^{43}$ Another said that her country had sought advice from international organizations on conducting impact assessments and was told it was impossible. ${ }^{44}$ Furthermore, a high turnover of staff means a lack of institutional memory, illustrated by the fact that negotiators were rarely aware of the considerations around treaties that they themselves had not worked on. ${ }^{45}$ Most of the negotiators from lower-income countries interviewed, who would be most likely to understand the situations in which investors would benefit from treaties, did not share the view that they would attract investment, even when they recognized that foreign investors in their country faced some double taxation. The skeptical views are illustrated by the quotes reproduced in table 3.1.

Other negotiators saw the matter differently, but they did not speak with any great confidence or certainty. "We do have the idea that it will attract investment," said one. ${ }^{46}$ Another negotiator, from a lower-income country, said, "You must understand that we are afraid of losing investment. We are a poor country and we're at the bottom of the pile." ${ }^{\prime 7}$ A private sector interviewee explained that a request to a company's home country government for a tax treaty with a country in which it was considering an investment would rarely be the deciding factor in an investment decision, but that it would come into play when evaluating the potential return on an investment, as a potential upside risk. ${ }^{48}$ While a few interviewees pointed to real examples of double taxation in lowerincome countries in the absence of tax treaties, ${ }^{49}$ the consensus appeared to be

TABLE 3.1. Quotes from lower-income country negotiators

\footnotetext{
A treaty is not a central factor to promote investment, it's more to eliminate double taxation. I would agree that a DTA is not a major factor driving investment. I know that there's a position that these treaties affect FDI, but I think it's not right. Most of the time developing countries are disadvantaged by treaties. Treaties do not attract investment. It is other factors.
}

Source: (In order, from top to bottom) Interview 37, Interview 23, Interview 4, Interview 20. 
that in most cases these examples were unlikely to be material to FDI decisions or limited to a small subset of investors.

One way to verify whether the active pursuit of tax treaties by lower-income countries has been underpinned by an understanding of the treaties' actual tax effects is to look for evidence that requests received by higher-income countries from lower-income countries coincided with interest from investors. If they did not, this would indicate that the absence of a treaty was unlikely to have been an impediment to investment flows. Because higher-income countries' tax treaty policymaking is quite sensitive to multinational companies' needs, and since the sacrifice of taxing rights entailed by a treaty is largely by the lower-income country, a higherincome country's response to a request for a tax treaty is generally quite indicative of whether a treaty will really resolve problems that are preventing investment.

According to one former treaty negotiator in a higher-income country, "Requests come from developing countries and may wait for years before there's a response." ${ }^{50}$ Another told me that this experience "is true to some extent, but our in-tray is not large." ${ }^{51}$ As Allison Christians observes, when examining the legal consequences of the absence of a tax treaty between Ghana and the United States, "in today's global tax climate, a typical tax treaty would not provide significant tax benefits to current or potential investors. Consequently, there is little incentive for these investors to pressure the U.S. government to conclude tax treaties with many LDCs . . . even if concluded, these treaties would not have a significant impact on cross-border investment and trade." 52

US diplomatic cables dated between 2004 and 2010 give numerous examples of lower-income countries seeking treaties with the United States. These include Vietnam, Hungary, Brunei, Croatia, Azerbaijan, Jordan, Malaysia, Libya, Honduras, and Turkmenistan. ${ }^{53}$ In most of these cases, no treaty has since been signed, and correspondence in the cables suggests that US reluctance was because US multinationals did not consider these treaties necessary. For example, a "scenesetter" for an assistant secretary of state ahead of a March 2007 visit to Macedonia noted that while that government wanted to sign a tax treaty with the United States during official visits later in the year, US businesses did not see any need for it: "Regarding the double taxation issue, we are studying the Macedonian draft proposal and have advised the MFA [Ministry of Foreign Affairs] that action on such agreements would require strong lobbying from US companies doing business in Macedonia, which has not yet been the case." 54

In December 2006, the US ambassador met with the Croatian foreign minister, noting "that the Barr Labs $\$ 2.5$ billion takeover of Pliva Pharmaceuticals may spur interest in concluding a double taxation treaty between the US and Croatia, and said he would be urging Washington to take a fresh look." ${ }^{55}$ Records of meetings with senior US Treasury officials illustrate this line consistently. In 
2007, Croatia's finance minister was told that "investments, such as Barr, will help make Croatia a higher priority" for a tax treaty. ${ }^{56}$ The following year, Qatar's finance and economy minister was informed that "the [US government] has limited resources to negotiate treaties and therefore has certain core requirements that would need to be addressed following consultation with U.S. companies to ensure that the proposed treaty would, in fact, address specific problems." 57

In some instances, then, the governments of lower-income countries have sought tax treaties despite (or in the absence of) analysis by their own expert officials about the likely impact of the treaty, or against these officials' views about an appropriate negotiating position. The response from higher-income countries, where tax treaty policy may be supported by a greater awareness of the likely impacts, has sometimes been to delay or decline such requests.

\section{Fiscal Costs versus Investment Benefits}

Tax treaties are at first sight a harder case to explain through bounded rationality than BITs. The costs of the latter are incurred only if an investor makes a claim against a signatory state at some point in the future, and hence those costs may be less salient to the policymaker. ${ }^{58}$ Many of the costs of tax treaties are immediate and significant: withholding tax revenue is reduced from the moment the tax treaty comes into force, and can be estimated in advance (although in interviews it became apparent that such forecasts are rarely made). Some other, larger costs emerge later and may be unanticipated - in particular, restrictions on capital gains charges, which have been the subject of legal disputes in countries such as Uganda years after a treaty was signed. ${ }^{59}$ The costs of tax treaty shopping, too, follow later, as investors construct tax planning structures using the new treaty. Furthermore, the growth in tax treaty diffusion has yet to level off. Even countries for which significant negative consequences of treaty conclusion have clearly become apparent have generally not stopped signing tax treaties, choosing instead to cancel or renegotiate some problematic treaties and carry on negotiating new ones. ${ }^{60}$

This poses a question: Why have some governments acted in spite of information about the fiscal costs, while others have not? In the tax competition literature, the focus has been on the ideological and institutional constraints on governments. ${ }^{61}$ Scott Basinger and Mark Hallerberg find that political costs faced by a government in the form of veto players and ideological opposition reduce the likelihood that it will cut corporate taxes in response to competitive pressure: the governments of competitor countries take into account the political costs of their competitors in setting their own corporate tax rates. ${ }^{62}$ Duane Swank shows 
that the "neoliberal" tax policies diffuse from the United States to other countries through a process of competition for mobile capital, which is conditioned by national institutions: coordinated market institutions impede diffusion, and liberal market institutions assist it. ${ }^{63}$ Thomas Plümper and colleagues consider how domestic constraints affect the balance between capital and labor taxes, demonstrating that fiscal constraints on a government as well as prevailing norms among voters constrain capital tax reductions. ${ }^{64}$ The latter paper also demonstrates that competition over corporate tax rates is more intense between adjacent countries. Stakeholders beyond the policy elite may conversely intensify tax competition if ideas about structural business power diffuse to the domestic constituencies that shape politicians' incentives. ${ }^{65}$

Tax treaties, however, differ from corporate tax rates in that, while their costs are just as real, their visibility is lower, and the number of de facto veto points they must pass through is also fewer ${ }^{66}$ In the UK Parliament, tax treaties are ratified as statutory instruments through a delegated legislation committee, which rarely discusses them in any detail and has never declined to ratify a treaty. ${ }^{67}$ In Canada, legislative scrutiny is similarly cursory. ${ }^{68}$ In Uganda, tax treaties are laid before parliament, but only for information purposes, and in Denmark, parliamentary approval was only introduced in the last few years. ${ }^{69}$ This lack of engagement by political actors illustrates that tax treaties are not clearly identified with any ideological positioning, most likely because they are regarded as serving a primarily administrative function. Furthermore, they reduce taxes on capital, which is generally considered a preference of the right, but they are also regarded as tools for investment promotion, which is a preference of the left because it may create jobs. There is no identifiable political constituency likely to oppose tax treaties, which may explain why they are rarely controversial. ${ }^{70}$ A government's preference for concluding tax treaties is therefore unlikely in most cases to be impeded by vetoes imposed by its domestic constituencies or within the political system (chapter 4 will discuss how conflict between political and bureaucratic actors may occur at veto points).

More pertinent, perhaps, to lower-income countries is the importance of the fiscal costs of the tax treaties to political actors. The "availability" of this information may vary. While governments do not routinely collect information on the taxes foregone through their treaties, such information becomes apparent when NGOs or the media highlight tax avoidance structures that exploit tax treaties, or when a court case over eligibility to treaty benefits thrusts particular elements of a treaty into the limelight. ${ }^{71}$ Fiscal cost information may also become more "available" if the underlying constraints on policy change. For example, political conditions may create incentives for a government to reexamine the tax 
revenue it raises from foreign investors, either because this is a vote-winning policy or because a government wants more tax revenue across the board to obtain autonomy from donors. Fiscal conditions may also influence how "available" the information about fiscal costs is: where tax revenue is scarce, or corporate tax makes up a larger share of total revenue, the revenue foregone through a treaty is likely to be a bigger concern. Finally, there is some evidence that individual policymakers differ in their predispositions to be concerned about fiscal costs. In one lower-income country, a finance ministry official who led treaty negotiations explained that "before we came, the leadership in Treasury felt that we were going to lose a lot of tax revenue. The perception then was that if we enter into these treaties we are going to lose tax." 72

The significance that policymakers give the revenue sacrifice resulting from a tax treaty is therefore an important element of the revenue raising / investment promotion trade-off. The case studies later in this book will illustrate that where ministers and officials are very conscious of the fiscal costs, they are more likely to resist pressure to sign treaties, whereas if raising tax revenue is less of a priority, they are more likely to acquiesce.

\section{Turning the Tables: Tax Treaties as Outward Investment Promotion Tools}

So far, following the existing literature on tax and investment treaty diffusion, I have focused entirely on competition among capital-importing countries. I now turn to another possibility, that competitive pressure might act on capital-exporting countries, driving them to seek tax treaties with lower-income countries. Mark Manger has argued, with respect to preferential trade agreements, that "concentrated interests in FDI-exporting countries have a strong incentive to lobby for preferential agreements because they confer specific advantages over competitors. To be politically attractive, these agreements must have a discriminatory effect on trade and investment with non-members." ${ }^{173}$

Such a position is certainly logical for tax treaties, which provide a tax advantage to firms investing outward into the treaty partner over their competitors from countries where such a treaty does not exist. Indeed, there is ample evidence that business lobbying, exercised in the home country rather than the host, has been at the origin of many tax treaties between higher-income and lower-income countries. At a discussion in the Danish Parliament in June 2015, for example, business pressure on the Danish government was very evident. A private sector participant stated that "Danish industry sees DTTs [double taxation treaties] as 
an important competition parameter," while Denmark's tax minister stated that "we have several times heard expressions of interest regarding Nigeria, but we have been unable to get them to sign." 74

In support of this proposition, a majority of negotiators interviewed from lower-income countries stated that their countries' patterns of treaty signatures were mainly the result of requests from other countries. "We're more or less on the waiting position. . . . They come to us," one stated. ${ }^{75}$ According to another, "Normally we negotiate when we receive requests, and have always responded positively. It's always a request from the other party."76 In this country's case, the treaty would be signed and ratified only after the treaty partner had pushed again, usually after further requests from the investor. Negotiators from two lowerincome countries that had signed their first tax treaties indicated that, once it became known that they were open to concluding agreements, they had been inundated with requests from capital-exporting countries. ${ }^{77}$

Higher-income countries formulate their negotiating priorities through consultation with their multinational businesses. Many have an established procedure to solicit private sector input into their future plans for treaty making. European treaty negotiators interviewed were all happy to say that their countries actively solicit business input into their annual treaty priorities, and that this was the main factor determining those priorities, alongside other diplomatic and economic matters. Some typical quotes from these interviews are given in table 3.2. The same applied to middle-income countries whose negotiators were interviewed, in respect to their treaties with lower-income countries.

Indeed, many individual treaties are the result of lobbying by a single multinational around a particular investment in a lower-income country. Talking about a particular treaty that had been concluded on his company's behalf, a business interviewee in a higher-income country said, "We were the first [to invest in that country] but they knew there would be others. ... If you went through any developing country and looked at big investments, you'd see a treaty just before or afterwards." ${ }^{\prime 8}$ In Nairobi, Kenya's 2007 tax treaty with France is widely understood among tax professionals from the public and private sectors to have been specifically linked to France Telecom's investment in the country, although this was denied by a Treasury official. "The entry of France Telecom into Telkom Kenya has yielded a tax benefit across all sectors with the signing of a double taxation treaty between Kenya and France," a local newspaper report noted at the time. ${ }^{79}$ Several interviewees from government and the private sector in different African and Asian countries hinted that certain tax treaties had been concluded in response to pressure from regional airlines.

Tax treaties are, therefore, frequently initiated at the behest of outward investors, via their home states, rather than by host country governments seeking to 
TABLE 3.2. Quotes from lower-income country negotiators

When we agree our treaty negotiation program the main concern is how it is going to benefit [our] companies.

It's a matter of competition: we're a small country.

We do have a treaty with [an African country] because at that time we had a construction company [investing there].

[If a competitor is from a treaty country] this will make it impossible for [our company] to compete.

Source: (In order, from top to bottom) Interview 21, Interview 14, Interview 19, Interview 13.

attract inward investment. Lower-income countries usually accept these requests to negotiate for a variety of reasons: a positive but passive attitude to tax treaties, diplomatic necessity, lack of capacity to analyze the costs and benefits, or simply because they are following the path of least resistance. Almost all the negotiators that I spoke with indicated that they never decline requests for tax treaties from higher-income countries, except from tax havens. "We never reject a request for negotiation. This has something to do with diplomacy and international relations," said one African negotiator. ${ }^{80}$ Several did indicate that responses to some requests might be deliberately stalled-for example, if it was politically necessary to conclude treaties in a certain order. ${ }^{81}$

\section{Coercion}

If the advantages of tax treaties accrue predominantly to the higher-income country signatory, and in many instances it is also the actions of that higherincome country that lead to the initiation of negotiations, this sheds a different light on why lower-income countries may have been willing - even enthusiasticto sign tax treaties. The organizing concept in this case is coercion, a term with a much broader meaning here than its common usage. Following Fabrizio Gilardi, I use "coercion" as an umbrella concept referring to a hierarchical process through which a third party changes a state's incentives rather than its preferences. ${ }^{82}$ Returning to Dobbin and colleagues' discussion of policy diffusion, three coercive mechanisms can be identified: changing material incentives through conditionality, changing material incentives through the formation of a policy consensus around a policy leader, and the influence of "hegemonic ideas." "What unites these studies," they say, "is their focus on the influence of an external source of pressure or ideas." 83

There is some limited evidence of explicit conditionality associated with tax treaties. For example, several negotiators indicated, always about other countries rather than their own, that Spain had threatened to withdraw tax-related technical 
assistance, and even aid funds, as part of treaty negotiations. ${ }^{84}$ British civil servants discussed using aid as leverage to obtain tax treaties in principle, but there is no evidence that they did so in practice. ${ }^{85}$ Examining tax treaties signed between aid donor and recipient countries, Julia Braun and Martin Zagler found on average a 22 percent increase in development assistance in the year a treaty was signed. ${ }^{86}$

There are more examples of higher-income countries insisting on a tax treaty as a quid pro quo for some other form of agreement. A US embassy cable from 2009 outlines Colombia's pursuit of free trade agreements (FTAs): "According to the [government of Colombia], Japan has insisted on negotiating a BIT (fourth negotiation round is in late November), followed by a DTT, before it will begin FTA negotiations with Colombia." 87

In 2007, Argentina requested a tax information exchange agreement (TIEA) with the United States. This is a kind of abridged tax treaty that would allow Argentina to obtain information about its citizens' US tax affairs, to help in investigations of potential tax evasion. The United States responded by stating that it was only willing to discuss a full tax treaty, which would give Argentina the same information but would also require Argentina to surrender some of its tax base to the United States. ${ }^{88}$ This led to a stalemate, which has yet to be resolved. According to the commissioner general of the Kenya Revenue Authority, Kenya received a similar response when it requested a TIEA with Singapore. ${ }^{89}$

The second form of coercion, policy leadership, occurs when a country or bloc with market power takes an action that changes incentives for other market actors - whether deliberately or not. Thus, since OECD countries have all adopted a common approach to international taxation based on bilateral tax treaties, lower-income countries have an incentive to do the same. As mentioned in chapter 2, OEEC members were aware of this when they began to discuss tax cooperation, and they gained a substantial first-mover advantage from acting together. Eduardo Baistrocchi frames these advantages using the concept of a network market, which creates three types of network effects that incentivize adoption of a particular policy instrument: positive externalities, whereby the detailed elaboration of model tax treaties and case law on their implementation reduces the transaction costs for other countries choosing to adopt them, and for taxpayers operating in those countries; an expectation among market actors that countries will follow the lead of the OECD countries; and "lock-in" effects, a concept similar to path dependency, in which the existing regime has significant sunk costs that make it difficult for new, incompatible entrants to the market to gain ground, even if they have advantages over the existing technology. ${ }^{90}$ In practical terms, this explains why lower-income countries might face a binary choice-sign OECD-type tax treaties or not at all-rather than supporting an alternative approach such as the CAN model. 
Finally, coercion through hegemonic ideas refers to how "dominant ideas become rationalized, often with elegant theoretical justifications, and influence how policy makers conceptualize their problems and order potential solutions." ${ }^{91}$ Norms emerge within a social hierarchy of states, and their association with this hierarchy is important: a norm may be more likely to spread in a universal way if it is associated with the behavior of an "advanced" state. ${ }^{92}$ It may reach a tipping point "beyond which adoption provides legitimacy rather than improves performance." Jas Jason Sharman suggests that governments in lower-income countries may emulate others in adopting reforms associated with being "developed," regardless of the content of those reforms, "to show peers and reassure policymakers themselves that they are in line with shared values." ${ }^{\text {94 }}$ To quote Kurt Weyland, writing within the bounded rationality framework, "Governments dread the stigma of backwardness and therefore eagerly adopt policy innovations, regardless of functional needs. ${ }^{95}$

As I argued earlier, the tax treaties myth is itself a hegemonic idea that influences policy preferences in lower-income countries through bounded rationality. Beyond its simplistic logic of double taxation, however, the association of tax treaties with the OECD, and the widespread participation in the regime by a growing number of countries, creates additional pressure for lower-income countries to join that may be unrelated to the underlying tax reasons. David Rosenbloom, a former US tax treaty negotiator, famously stated that many lowerincome countries regard tax treaties as a "badge of international economic respectability." ${ }^{\prime 96}$ Arianne Pickering, a former Australian treaty negotiator, concurs that "a country may want to signal to the global economy and potential investors that it is a responsible member of the international tax community that is willing and able to conform with widely-accepted tax rules and norms." ${ }^{97}$

By concluding a tax treaty for broader reputational reasons, policymakers may therefore be acting in a purely rational incentive-driven way, making a conscious instrumental calculation based on a logic of consequences such as the tax treaties myth. Alternatively, they may be following a logic of appropriateness, taking for granted a norm that associates tax treaties with the way "advanced" countries behave. ${ }^{98}$

\section{Conclusion}

This chapter focused on the preferences of nonspecialist actors. It modified the standard model of tax competition, which is assumed to motivate lower-income countries to conclude tax treaties, in two ways. First, the tax treaties myth provided a "cognitive shortcut" for policymakers filtering information in a boundedly 
rational manner. This argument is similar to that used to explain the spread of BITs, but it is a harder case to explain because the costs of tax treaties are immediate and foreseeable, unlike those of BITs, which are uncertain and occur in the future. Thus, the "availability" of information about these costs is critical to the bounded rationality framework. In particular, when governments are focused on maximizing corporate tax revenue, those costs may be more salient, which means that such information may be more cognitively "available" than it is for governments with other sources of income.

The second change from the standard account of tax competition was to switch the focus onto competition among capital exporters. As a tool for attracting inward investment, a tax treaty is an odd choice, because it has the distorting effect of lowering tax costs for foreign investors from one country in comparison with those from other countries in the host country market. In contrast, for capitalexporting countries, the effect of that distortion is to give their outward investors a competitive advantage in the lower-income country over investors from other countries. For this reason, and as the evidence provided showed, it is commonly capital exporters that initiate tax treaty negotiations, not capital-importing lowerincome countries.

Three mechanisms of coercion in the diffusion literature offer explanations for why a lower-income country would respond positively to a request from a higher-income country. First, capital-exporting countries have levers, such as aid budgets and sovereign wealth funds, that might change a lower-income country's incentives. Second, the first-mover advantage of OECD states creates incentives for other countries to sign treaties that are compatible with their approach to international tax. Third, the hegemonic idea of the tax treaties myth, or even that signing tax treaties is what advanced countries do, permeates analysis of tax treaties in lower-income countries. Having focused on ideas about tax treaties among policymakers who do not have a deep specialism in the subject, the book shifts its focus in the next chapter to look at international tax specialists, for whom tax treaties serve an altogether different purpose. 